\title{
Untreated Depression During Pregnancy and Its Effect on Pregnancy Outcomes: A Systematic Review
}

\author{
Nasrin Jahan ${ }^{1}$, Terry R. Went ${ }^{2}$, Waleed Sultan $3,2,4$, Alisha Sapkota ${ }^{1}$, Hajra Khurshid ${ }^{1}$, Israa A. Qureshi \\ , Michael Alfonso 6, 2 \\ 1. Psychiatry, California Institute of Behavioral Neurosciences \& Psychology, Fairfield, USA 2. Medicine, California \\ Institute of Behavioral Neurosciences \& Psychology, Fairfield, USA 3. Medicine, Beni Suef University Faculty of \\ Medicine, Beni Suef, EGY 4. Surgery, Halifax Health Medical Center, Daytona Beach, USA 5. Internal Medicine, \\ California Institute of Behavioral Neurosciences \& Psychology, Fairfield, USA 6. School of Medicine, Universidad del \\ Rosario, Bogota, $\mathrm{COL}$
}

Corresponding author: Nasrin Jahan, nasrinkabita@gmail.com

\begin{abstract}
Depression is characterized by sad, irritated, or empty moods, as well as somatic and cognitive changes such as loss of concentration, anhedonia, hopelessness, loss of appetite, sleep disturbances, and suicidal ideation, all of which have a negative impact on an individual's ability to function. Depression that occurs during pregnancy is known as antenatal depression. The occurrence of depression during pregnancy and afterward is quite high. Women having a history of depression before pregnancy have a high probability of getting depression during pregnancy again. The purpose of the study is to review the effect of untreated depression during pregnancy on maternal and neonatal outcomes. The primary outcomes of this review were the identification of studies showing the relationship between untreated depression during the pregnancy indicated by depression measures and any associated adverse birth outcomes; specifically, low birth weight, small for gestational age, preterm birth, postpartum depression, and infant neurodevelopmental outcome. We reviewed 20 population-based contemporary cohort studies with a range of populations from 54 to 194,494 , all of them representing the population of gestational age located in multiple jurisdictions. It was found that maternal depression during pregnancy has a positive association with preterm birth, small for gestational age, stillbirth, low birth weight, and maternal morbidity including perinatal complications, increased operative delivery, and postpartum depression. To prevent these adverse outcomes, depression should be screened, monitored, and managed appropriately keeping risk-benefit in consideration.
\end{abstract}

Received 07/18/2021 Review began 08/06/2021 Review ended 08/11/2021 Published 08/17/2021

๑) Copyright 2021 Jahan et al. This is an open access article distributed under the terms of the Creative Commons Attribution License CC-BY 4.0., which permits unrestricted use, distribution, and reproduction in any medium, provided the original author and source are credited.
Categories: Obstetrics/Gynecology, Psychiatry

Keywords: untreated depression, maternal depression, pregnancy outcomes, maternal outcomes, neonatal outcomes

\section{Introduction And Background}

Depression is defined as a state of sadness, irritability, or empty moods, as well as somatic and cognitive changes such as loss of concentration, anhedonia (lack of pleasure), hopelessness, loss of appetite, sleep disturbances, and suicidal ideation, all of which have a negative impact on an individual's ability to function. Depression that occurs during pregnancy is called prenatal or antenatal depression. Prenatal depression should be identified and treated like postpartum depression. However, prenatal depression is repeatedly not considered a vital health issue. According to the American College of Obstetricians and Gynecologists, clinicians should screen for prenatal depression with a standard tool at least once during pregnancy. Despite a patient having been diagnosed with depression, treatment is often declined because of concerns regarding the baby's health. Although there are several studies on prenatal depression, the research results of the depression on the pregnancy outcomes were unpredictable. Prenatal depression has been linked to preterm delivery, low birth weight, and intrauterine growth restriction in some studies, whereas depression has been found to not affect pregnancy outcomes such as preterm birth, low birth weight, and poor Apgar scores in others [1].

Based on the current Diagnostic and Statistical Manual of Mental Disorders, 5th edition (DSM5), major depression is diagnosed by the presence of five out of nine stated symptoms within two weeks and having a considerable negative influence on the previous functioning [2]. It mentions that the symptoms should not be attributable to another medical condition and, in this case, pregnancy. Antenatal depression falls under the specifier termed "with peripartum onset." The mood episodes may present with or without psychotic features. Diagnostic criteria consist of depressed mood, considerably lessened interest or pleasure in most activities, psychomotor retardation, or agitation, feeling of worthlessness or inappropriate guilt, impaired thinking or concentration, and repeated thoughts of death [2]. Somatic symptoms including significant weight and appetite variations, and changes in sleep patterns and fatigue, may also appear in any normal pregnancy due to neuroendocrine physiological changes [3].

Major depressive disorder, also known as clinical depression, is common in women of childbearing age [4]. 
The prevalence of postpartum depression is $17 \%$, while the incidence of prenatal depression is as high as $20 \%$ to $40 \%$. Depression rates during pregnancy have been reported to be as high as $7.4 \%$ in the first trimester, $12.0-12.8 \%$ in the second and third trimesters, and even higher rates in the first year after delivery [1]. Women with a history of depression before pregnancy are especially at risk with high depression relapse rates during pregnancy $[4]$.

There are several risk factors related to the increased risk of developing depressive symptoms during pregnancy that has been studied particularly in low- and middle-income countries. A study performed by Howard et al. (2013) revealed that intimate partner violence was significantly coupled with depression during pregnancy [2]. On the other hand, Fischer et al. (2012) found that life stress and major adverse life events, poor socioeconomic status, absence of perceived social or relationship support, unwanted or unintended pregnancies, and the decision made by some women or their clinicians to stop antidepressant maintenance medications were a key risk factor in increasing depression in the antenatal period [2]. Prior history of psychopathology that is largely related to depression, preconception anxiety, and young age is also correlated with the risk of developing clinical depression during pregnancy. Other elements thought to predispose to depression in the general population include genetic and hormonal susceptibility, chronic illness e.g., acquired immunodeficiency syndrome (AIDS), and personality traits [2].

Depression can have major repercussions for both the mother and the fetus if it occurs during pregnancy. Some of those consequences linked to prenatal depression are slower fetal development, abortion, low birth weight, preterm labor, preterm birth, maternal anemia and diabetes, hypertensive disorders (including preeclampsia), cesarean section (CS), and postpartum depression. Infants born to mothers who are depressed during pregnancy are more irritable, less active, and more likely to experience developmental delays. Prenatal depression also raises the risk of postpartum depression, and the infant's health and growth may be harmed if the mother is depressed for an extended period. Despite the severe consequences of prenatal depression and the possibility that proper screening and treatment may help to reduce adverse birth outcomes, most research has concentrated exclusively on postpartum depression [5].

Pregnancy is a significant driver of antidepressant drug discontinuation, and most women do not get additional antidepressant prescriptions after six weeks of pregnancy. Despite the significance of depression, screening for it is neglected, avoiding treatment and measures to prevent the escalation of symptoms and their effects; then, oftentimes when depression is identified, it is frequently left untreated [5]. Even though women should be screened and treated before conception, many women go into pregnancy with untreated depression [6]. Hence, this study aims to review the effect of untreated depression during pregnancy on maternal and neonatal outcomes.

\section{Review}

\section{Methods}

Literature Search

We followed the Preferred Reporting Items for Systematic Reviews and Meta-Analyses (PRISMA) guidelines for this systematic review. We conducted a systematic literature review where two authors (JN and WT) independently searched Medline in PubMed, PubMed Central (PMC), and Google Scholar databases for relevant articles from January 2014 up to April 2021, and additional papers were retrieved due to relevance. After this process, duplicates were removed, and manual screening was performed to select relevant studies.

The primary outcomes of this review were identification of studies indicating the relationship between untreated depression during the pregnancy indicated by depression measures and any associated adverse birth outcomes; specifically, preterm birth, low birth weight, small for gestational age, postpartum depression, and infant neurodevelopmental outcomes such as autism spectrum disorder (ASD), attention deficit hyperactivity disorder (ADHD), anxiety, and depression. Additional new studies were identified manually using citation searches based on their relevancy.

\section{Inclusion Criteria}

Papers fulfilling following criteria were included during the literature search from database and registry: (a) results retrieved based on a literature search of English language articles only; (b) only included studies published between January 1st, 2014 and April 30th, 2021; (c) full text papers; (d) studies conducted on humans; (e) women of childbearing age between 14 and 45 years; (f) only articles clearly focused on untreated gestational depression; (g) studies where depression/depressive symptoms were included as a primary independent variable and preterm birth (PTB), low birth weight (LBW), small for gestational age (SGA), spontaneous abortion, maternal effects including preeclampsia, cesarean section (CS), operative vaginal delivery, increase use of epidural analgesia during delivery, suicidal ideation, and the development of postnatal depression were consequence of primary independent variable; (h) population-based, cohort, and case control studies; (i) studies that used self-reported questionnaires or organized psychiatric interviews to assess depression, anxiety, and stress symptoms in all pregnant women; and ( $\mathrm{j}$ ) articles in which proven diagnostic or screening techniques were used to detect depression. 
Studies with the following criteria were excluded: (a) non-human studies; (b) study focused on stress and anxiety; (c) the use of antidepressant medication was the focus, rather than the measurement and diagnosis of depression; (d) patients that reported use of antidepressant during pregnancy also were excluded; and (e) articles in languages other than English.

\section{Search Strategy}

The keywords used during the search were "depression during pregnancy," "pregnancy outcomes," "perinatal outcome," "preterm birth," "neonatal outcome," and "female."

A methodical search of the databases mentioned was conducted on May 1, 2021. The search for relevant studies using generic keywords and MeSH terms was the following: "depression during pregnancy" AND "pregnancy outcomes” OR “perinatal outcome” OR "preterm birth" OR "neonatal outcome” AND “female.” Periods between January 1st, 2014, and April 30th, 2021, were addressed. A total of 1,225 studies were identified. After removing 38 duplicate articles, 1187 unique articles were identified.

Screening

We evaluated the titles of all the citations received from electronic database searches for the first stage of screening and eliminated any that were not focused on untreated gestational depression. The abstract review of accessible publications (either free or through access privilege as a member of an educational institution) was the second stage of screening, and full-text inclusion and exclusion criteria were applied. Such screening resulted in the identification of 24 articles. Full-text articles were obtained for these screened abstracts except for three of them which were not accessible. In addition, two new studies were identified via citation search where inclusion and exclusion criteria were met. Full-text articles were accessed for all of them.

Critical Appraisal of the Literature

The study quality was assessed independently by two investigators (JN and WT) for all 23 articles screened and accessed. All of them are cohort study while one of them is a nested case-control study. We used the Newcastle-Ottawa Scale (NOS) for the assessment of study quality. The total NOS score was 9, which was suitable for evaluating case-control studies (selection, comparability, and exposure) and cohort studies (selection, comparability, and outcome). These studies were deemed to be high quality, with all studies having at least a 7 NOS score.

\section{Results}

Our search in databases and registers resulted in 1,225 articles. After removing 38 duplicates, we went through titles and abstracts obtaining 24 articles. We could access 21 of them, while the other three were not accessible, so we excluded those papers. After going over full-text papers, we excluded three more papers as they were not addressing our research question. In addition, we identified two more articles through citation search. We selected 18 articles plus two additional articles, which were assessed for the quality of the studies by using NOS. All 20 articles were cohort studies. Brief details of these steps are available in the flow diagram below (Figure 1) [7]. 


\section{Cureus}

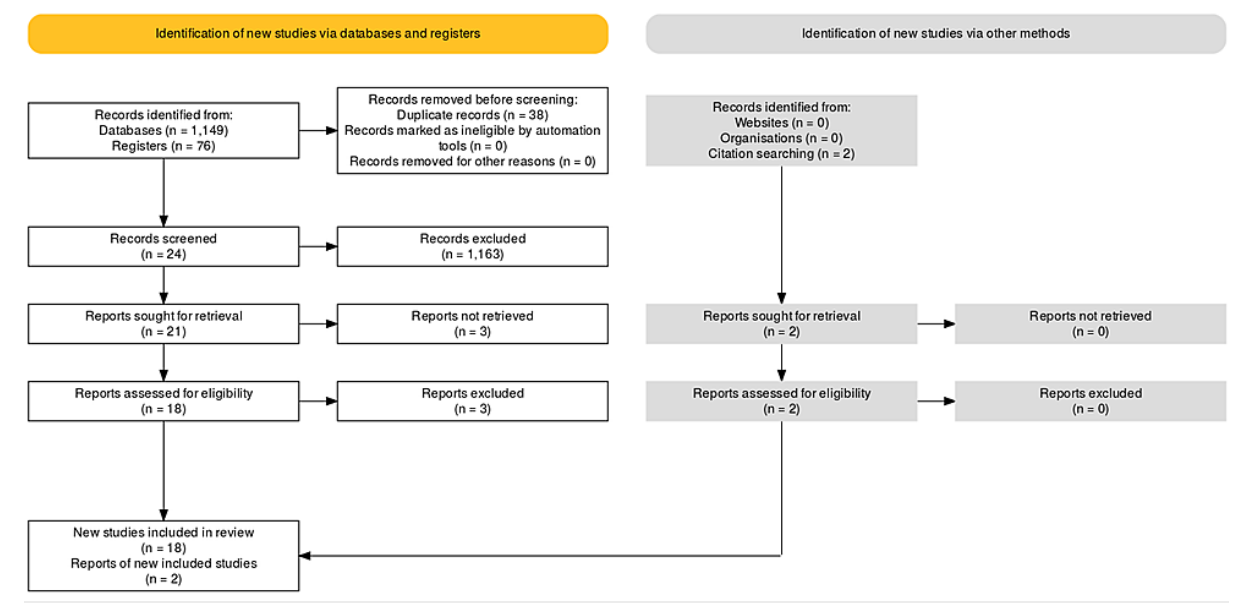

\section{FIGURE 1: PRISMA 2020 flow diagram}

PRISMA, Preferred Reporting Items for Systematic Reviews and Meta-Analyses.

Identification of Studies via Database and Register

All these 20 studies were population-based cohort studies with a range of population from 54 to 194,494, representing the population of gestational age located in multiple jurisdictions. Study characteristics, i.e., data collection method and study sets, differ, but in common, all these studies utilized data that were collected from individual subjects. Most of the studies measured depression during pregnancy using the Edinburgh Postnatal Depressive Scale (EPDS), while few others relied on the Center for Epidemiological Studies-Depression (CES-D), Patient Health Questionnaire-9 (PHQ9), Beck Anxiety Inventory (BAI), and custom questionnaires. These studies exhibit information regarding the association of gestational depression with the impact it has over a wide range of outcomes, making a special emphasis on low birth weight, preterm birth, postpartum depression, and infant neurodevelopmental outcome. We tabulated these 20 articles to evaluate the indicated association between untreated depression during the pregnancy in the context of proper depression measures and any associated adverse birth outcomes. A summary is available in Table 1 as follows:

\begin{tabular}{|c|c|c|c|c|c|c|c|}
\hline $\begin{array}{l}\text { Authors } \\
\text { and year }\end{array}$ & Study types & Purpose of study & Study characteristics & $\begin{array}{l}\text { Sample } \\
\text { size }\end{array}$ & $\begin{array}{l}\text { Depression } \\
\text { measures }\end{array}$ & Actual result & Conclusion \\
\hline $\begin{array}{l}\text { Weobong } \\
\text { et al. } \\
(2014) \text { [8] }\end{array}$ & Cohort study & $\begin{array}{l}\text { To investigate the } \\
\text { effects of } \\
\text { depression on a } \\
\text { baby's survival }\end{array}$ & $\begin{array}{l}\text { To identify pregnancies } \\
\text { and collect data on births } \\
\text { and deaths, a cohort study } \\
\text { was placed within four- } \\
\text { weekly surveillance of all } \\
\text { women of reproductive age }\end{array}$ & $\begin{array}{l}n= \\
20,679\end{array}$ & $\begin{array}{l}\text { PHQ9 to } \\
\text { ascertain and } \\
\text { DSM-IV to } \\
\text { determine } \\
\text { major or minor } \\
\text { depression }\end{array}$ & $\begin{array}{l}\text { Premature labor, peripartum difficulties, } \\
\text { postpartum complications, non-vaginal } \\
\text { delivery, infant sickness, and bed net use } \\
\text { during pregnancy were found linked, but } \\
\text { neonatal fatalities, stillbirths, low birth } \\
\text { weight, immediate breastfeeding initiation, or } \\
\text { exclusive breastfeeding did not indicate any } \\
\text { link }\end{array}$ & $\begin{array}{l}\text { This leads to } \\
\text { premature } \\
\text { labor, } \\
\text { peripartum } \\
\text { difficulties, } \\
\text { postpartum } \\
\text { complications, } \\
\text { non-vaginal } \\
\text { delivery, infant } \\
\text { sickness, and } \\
\text { bed net use } \\
\text { during } \\
\text { pregnancy }\end{array}$ \\
\hline $\begin{array}{l}\text { Xu et al. } \\
\text { (2020) [1] }\end{array}$ & Cohort study & $\begin{array}{l}\text { To see if prenatal } \\
\text { depression } \\
\text { throughout late } \\
\text { pregnancy has an } \\
\text { impact on maternal } \\
\text { and infant } \\
\text { outcomes }\end{array}$ & $\begin{array}{l}\text { Clinical data of subjects } \\
\text { were divided into three } \\
\text { groups: mild-to-moderate } \\
\text { depression, severe } \\
\text { depression, and non- } \\
\text { depression }\end{array}$ & $\mathrm{n}=595$ & $\begin{array}{l}\text { Edinburgh } \\
\text { Postnatal } \\
\text { Depressive } \\
\text { Scale (EPDS) }\end{array}$ & $\begin{array}{l}\text { Pregnant patients with severe depression } \\
\text { were more likely to have preterm delivery } \\
\text { than women without depression or with mild- } \\
\text { to-moderate depression }\end{array}$ & $\begin{array}{l}\text { Preterm birth is } \\
\text { substantially } \\
\text { linked to severe } \\
\text { prenatal } \\
\text { depression } \\
\text { throughout late } \\
\text { pregnancy, } \\
\text { whereas mild- } \\
\text { to-moderate } \\
\text { prenatal } \\
\text { depression had } \\
\text { little effect on }\end{array}$ \\
\hline
\end{tabular}




\section{Cureus}

\begin{tabular}{|c|c|c|c|c|c|}
\hline $\begin{array}{l}\text { Mochache } \\
\text { et al. } \\
\text { (2018) [3] }\end{array}$ & Cohort study & $\begin{array}{l}\text { The goal of this } \\
\text { study was to see if } \\
\text { prenatal } \\
\text { depression is } \\
\text { linked to preterm } \\
\text { birth }\end{array}$ & $\begin{array}{l}\text { Even though } 292 \text { women } \\
\text { were recruited, only } 255 \\
\text { were successfully followed } \\
\text { up to delivery, owing to a } \\
12.7 \% \text { attrition rate }\end{array}$ & $n=292$ & $\begin{array}{l}\text { Edinburgh } \\
\text { Postnatal } \\
\text { Depression } \\
\text { Scale (EPDS) }\end{array}$ \\
\hline $\begin{array}{l}\text { Szegda et } \\
\text { al. (2017) } \\
\text { [4] }\end{array}$ & Cohort study & $\begin{array}{l}\text { To look at the } \\
\text { associations } \\
\text { between } \\
\text { depression, } \\
\text { preterm birth, and } \\
\text { small for } \\
\text { gestational age }\end{array}$ & $\begin{array}{l}\text { Early, mid, and late } \\
\text { pregnancy interviews were } \\
\text { conducted }\end{array}$ & $\begin{array}{l}n= \\
1,262\end{array}$ & $\begin{array}{l}\text { Edinburgh } \\
\text { Postnatal } \\
\text { Depression } \\
\text { Scale (EPDS) }\end{array}$ \\
\hline $\begin{array}{l}\text { Fekadu } \\
\text { Dadi et al. } \\
\text { (2020) [9] }\end{array}$ & Cohort study & $\begin{array}{l}\text { To determine the } \\
\text { prevalence of } \\
\text { unfavorable birth } \\
\text { outcomes, as well } \\
\text { as the direct and } \\
\text { indirect pathways } \\
\text { through which } \\
\text { depression and } \\
\text { other psychosocial } \\
\text { risk factors may } \\
\text { influence these } \\
\text { outcomes }\end{array}$ & $\begin{array}{l}\text { Women in their second or } \\
\text { third trimester were } \\
\text { followed for a month after } \\
\text { giving birth }\end{array}$ & $n=916$ & $\begin{array}{l}\text { Edinburgh } \\
\text { Postnatal } \\
\text { Depression } \\
\text { Scale (EPDS) }\end{array}$ \\
\hline
\end{tabular}

In general, there was no association between antenatal depression and preterm birth. However, depression was modified by partner support and stress coping ability, and preterm birth was 4.38 and 4.99 times higher for those with poor spouse support and poor stress coping ability

outcomes

Those with depressive symptoms had a 3.8 times increased risk of giving birth

There was a link between prenatal depression and premature labor and delivery

Mid-pregnancy depression

Mid-pregnancy depression increased the risk for SGA. SGA was not associated with late pregnancy depression; preterm birth was not associated with depression during pregnancy

increased the incidence of SGA in this cohort of mostly Puerto Rican women

No association is indicated between

antenatal depression and preterm birth

To see if antenatal depressed

symptoms have an impact on obstetric

Choi et al. (2014) [10] Cohort study there are any links between antenata and postpartum depression

Pregnant women in their third trimester of pregnancy who were getting obstetrical care; participants were split into two groups based on EPDS scores: non-depressed ( $\mathrm{n}=$ 344, EPDS score 9) and depressed ( $n=123$, EPDS level 10)

Edinburgh Postnatal

Depression Scale (EPDS)
To estimate the risk of ASD in Cohort study children of women

Hagberg with nested who had et al. sibling case- depression during

(2018) [11] control

Benatar et al. (2020) Cohort study [5] analysis

\section{antidepressants \\ compared to those}

pregnancy and use

who were not

\section{To find out how}

common

depression is

From 2013 to 2017,

Medicaid individuals

among pregnant registered in Strong Start

Medicaid recipients

for Mothers and

and what the link is

between
2 , a national preterm birth prevention program, with a 2-month history of

and a three-year follow-up

depression

population

With EPDS scores of $\geq 10,26.34 \%(n=123)$

of the 467 patients exhibited prenatal

depressive symptoms. Prenatal depression

symptoms were not linked to any significant perinatal consequences. A total of 192

women from the initial study cohort were

given the EPDS again as a follow-up during the postpartum period. A total of 56

(29.17\%) of the 192 participants received a score of 10 or higher. The prenatal and postpartum EPDS scores had a Spearman correlation coefficient of 0.604 , which was statistically significant $(P=0.001)$

Antenatal

depression is

not associated

with poor

perinatal

outcomes.

Screening for

antenatal

depression, on

the other hand,

may be useful in

identifying

women at risk

of postpartum

depression

Women who

are depressed

during

pregnancy have

a higher risk of

having a child

with ASD,

regardless of

whether they

take

antidepressants

Depression is

positively

correlated to

preterm birth,

low birth

weight, and 


\section{Cureus}

\begin{tabular}{|c|c|c|c|c|c|c|c|}
\hline & & $\begin{array}{l}\text { depression and } \\
\text { pregnancy } \\
\text { outcomes }\end{array}$ & \multicolumn{2}{|l|}{$\begin{array}{l}\text { single pregnancy and } \\
\text { reliable depression data }\end{array}$} & $\begin{array}{l}\text { Studies - } \\
\text { Depression } \\
\text { [CES-D] scale) }\end{array}$ & $\begin{array}{l}\text { probability of C-section birth }(28.8 \% \text { vs. } \\
26.3 \%) \text { than women who are not depressed }\end{array}$ & $\begin{array}{l}\text { probability of C- } \\
\text { section }\end{array}$ \\
\hline $\begin{array}{l}\text { Flynn et al. } \\
\text { (2015) [12] }\end{array}$ & Cohort study & $\begin{array}{l}\text { To find the effect } \\
\text { of prenatal } \\
\text { depression and } \\
\text { anxiety on key } \\
\text { infant outcomes } \\
\text { (gestational age at } \\
\text { birth, birth weight, } \\
\text { and Apgar scores), } \\
\text { and maternal } \\
\text { medical conditions }\end{array}$ & $\begin{array}{l}\text { Women who were } \\
\text { presenting consecutively } \\
\text { for prenatal care at a health } \\
\text { system serving primarily } \\
\text { Medicaid patients and } \\
\text { information on maternal } \\
\text { characteristics, maternal } \\
\text { medical health as well as } \\
\text { mental health were } \\
\text { extracted }\end{array}$ & $\mathrm{n}=419$ & $\begin{array}{l}\text { Patient Health } \\
\text { Questionnaire-9 } \\
\text { (PHQ-9) and } \\
\text { obstetrics } \\
\text { clinician } \\
\text { documentation } \\
\text { of depression } \\
\text { or anxiety }\end{array}$ & $\begin{array}{l}\text { This study suggests that the interaction of } \\
\text { prenatal depression and anxiety with medical } \\
\text { conditions may have a greater impact on } \\
\text { birth weight and gestational age }\end{array}$ & $\begin{array}{l}\text { Prenatal } \\
\text { depression and } \\
\text { anxiety affect } \\
\text { birth weight and } \\
\text { gestational age }\end{array}$ \\
\hline $\begin{array}{l}\text { Yang et al. } \\
\text { (2017) [13] }\end{array}$ & $\begin{array}{l}\text { A population- } \\
\text { based cohort } \\
\text { study was } \\
\text { used to } \\
\text { create a } \\
\text { nested case- } \\
\text { control study }\end{array}$ & $\begin{array}{l}\text { To find the effect } \\
\text { of depression, } \\
\text { anxiety, and both } \\
\text { on low birth weight } \\
\text { (LBW); and to } \\
\text { examine if preterm } \\
\text { birth (PTB) } \\
\text { moderates these } \\
\text { associations }\end{array}$ & $\begin{array}{l}\text { The study used the } \\
\text { Electronic Perinatal Health } \\
\text { Care Information System to } \\
\text { extract cases and controls }\end{array}$ & $\begin{array}{l}\mathrm{n} \\
\text { (cases) } \\
=5,457 ; \\
\mathrm{n} \\
\text { (control) } \\
=2,853\end{array}$ & $\begin{array}{l}\text { Custom } \\
\text { questionnaire }\end{array}$ & $\begin{array}{l}\text { Depression and anxiety during pregnancy } \\
\text { (DADP) are related to a greater incidence of } \\
\text { LBW, with PTBs having the strongest } \\
\text { association }\end{array}$ & $\begin{array}{l}\text { The presence of } \\
\text { DADP was } \\
\text { associated with } \\
\text { an increased } \\
\text { risk of LBW }\end{array}$ \\
\hline $\begin{array}{l}\text { Nutor et } \\
\text { al. (2018) } \\
{[14]}\end{array}$ & $\begin{array}{l}\text { Retrospective } \\
\text { cohort study }\end{array}$ & $\begin{array}{l}\text { The goal of this } \\
\text { study was to look } \\
\text { at the relationship } \\
\text { between } \\
\text { depressive } \\
\text { symptoms and } \\
\text { preterm birth while } \\
\text { controlling for } \\
\text { social support, } \\
\text { both general and } \\
\text { from the baby's } \\
\text { father }\end{array}$ & $\begin{array}{l}\text { Women were interviewed } \\
\text { during their postpartum } \\
\text { hospitalization } 24 \text { to } 48 \\
\text { hours after birth. Medical } \\
\text { records were used to } \\
\text { obtain information about } \\
\text { the neonates and their } \\
\text { mothers' health }\end{array}$ & $\begin{array}{l}n= \\
1,207\end{array}$ & $\begin{array}{l}\text { Center for } \\
\text { Epidemiological } \\
\text { Studies- } \\
\text { Depression } \\
\text { (CES-D); CES-D } \\
\text { scores } \geq 23 \\
\text { considered } \\
\text { severe }\end{array}$ & $\begin{array}{l}\text { Around } 17 \% \text { of the women in the sample } \\
\text { had a PTB, while } 20 \% \text { of the women in the } \\
\text { sample had a CES-D score of } \geq 23 \text {. After } \\
\text { adjusting for both general social support and } \\
\text { father of the baby support, women with a } \\
\text { CES-D score of }>23 \text { were nearly } 70 \% \text { more } \\
\text { likely to have a PTB than women with a CES- } \\
\text { D score of }<23 \text { (PR }=1.68,95 \% \text { Cl: } 1.24- \\
2.16 \text { ) }\end{array}$ & $\begin{array}{l}\text { Women with } \\
\text { severe } \\
\text { depression } \\
\text { were almost } \\
\text { twice more } \\
\text { likely to have } \\
\text { PTB compared } \\
\text { with women } \\
\text { with not severe } \\
\text { depression }\end{array}$ \\
\hline $\begin{array}{l}\text { Smith et } \\
\text { al. (2015) } \\
{[15]}\end{array}$ & $\begin{array}{l}\text { Retrospective } \\
\text { cohort study }\end{array}$ & $\begin{array}{l}\text { To investigate } \\
\text { whether maternal } \\
\text { depression during } \\
\text { pregnancy affected } \\
\text { adverse birth } \\
\text { outcomes, } \\
\text { specifically preterm } \\
\text { birth and small for } \\
\text { gestational age } \\
\text { (SGA) }\end{array}$ & $\begin{array}{l}\text { Used the Utah Pregnancy } \\
\text { Risk Assessment } \\
\text { Monitoring System, which } \\
\text { is an ongoing surveillance } \\
\text { initiative that analyzes } \\
\text { maternal behaviors in } \\
\text { women who have recently } \\
\text { given birth }\end{array}$ & $\begin{array}{l}n= \\
4,123\end{array}$ & $\begin{array}{l}\text { Custom } \\
\text { questionnaire }\end{array}$ & $\begin{array}{l}\text { Women who were told they had depression } \\
\text { by a doctor, nurse, or other health care } \\
\text { worker during pregnancy had statistically } \\
\text { significantly increased odds of preterm birth } \\
\text { as compared to women who were not told } \\
\text { they had depression. However, after } \\
\text { adjustment for prenatal care visits, the } \\
\text { depression-preterm birth association was } \\
\text { attenuated and no longer statistically } \\
\text { significant }\end{array}$ & $\begin{array}{l}\text { The findings of } \\
\text { this study do } \\
\text { not find the } \\
\text { correlation } \\
\text { between } \\
\text { maternal } \\
\text { depression and } \\
\text { adverse birth } \\
\text { outcomes }\end{array}$ \\
\hline $\begin{array}{l}\text { Li et al. } \\
\text { (2020) [16] }\end{array}$ & $\begin{array}{l}\text { Prospective } \\
\text { cohort study }\end{array}$ & $\begin{array}{l}\text { To examine the } \\
\text { associations of } \\
\text { antenatal } \\
\text { depression } \\
\text { symptoms with } \\
\text { pregnancy } \\
\text { outcomes, } \\
\text { especially for low } \\
\text { birth weight }\end{array}$ & $\begin{array}{l}\text { Unfavorable outcomes in } \\
\text { pregnant women with } \\
\text { prenatal depression were } \\
\text { calculated using } \\
\text { multivariate logistic } \\
\text { regression (Cl) that } \\
\text { represented as odds ratio } \\
\text { (OR) and } 95 \% \text { confidence } \\
\text { interval (Cl) }\end{array}$ & $\begin{array}{l}n= \\
1,377\end{array}$ & $\begin{array}{l}\text { The Edinburgh } \\
\text { Postnatal } \\
\text { Depression } \\
\text { Scale (EPDS) } \\
\text { questionnaire } \\
\text { was used to } \\
\text { assess } \\
\text { depressive } \\
\text { symptoms in } \\
\text { the second } \\
\text { trimester of } \\
\text { pregnancy; } \\
\text { EPDS } \geqq 12 \\
\text { scores were } \\
\text { included }\end{array}$ & $\begin{array}{l}\text { After adjusting for maternal age, education, } \\
\text { parity, pre-pregnancy BMI, residential region, } \\
\text { and fetal gender, an EPDS score of } \geq 12 \text { (vs. } \\
<12 \text { ) was attributed to an elevated risk of low } \\
\text { birth weight but not preterm birth, large for } \\
\text { gestational age, small for gestational age, or } \\
\text { macrosomia }\end{array}$ & $\begin{array}{l}\text { Low birth } \\
\text { weight is linked } \\
\text { to maternal } \\
\text { depression, } \\
\text { although there } \\
\text { is no link to } \\
\text { preterm birth, } \\
\text { SGA, LGA, or } \\
\text { macrosomia }\end{array}$ \\
\hline & & $\begin{array}{l}\text { To determine if } \\
\text { there is a } \\
\text { relationship }\end{array}$ & Women with a gestational & & & & An increased \\
\hline
\end{tabular}




\section{Cureus}

\begin{tabular}{|c|c|c|c|c|c|c|c|}
\hline $\begin{array}{l}\text { Rawahi et } \\
\text { al. (2020) } \\
\text { [17] }\end{array}$ & $\begin{array}{l}\text { Prospective } \\
\text { cohort study }\end{array}$ & $\begin{array}{l}\text { between antenatal } \\
\text { depression and } \\
\text { pregnancy } \\
\text { outcomes, } \\
\text { including the risk } \\
\text { of postpartum } \\
\text { depression }\end{array}$ & $\begin{array}{l}\text { age of } \geq 32 \text { weeks who } \\
\text { were receiving antenatal } \\
\text { care at } 12 \text { local health } \\
\text { centers in Muscat, Oman, } \\
\text { were invited to participate }\end{array}$ & $\mathrm{n}=959$ & $\begin{array}{l}\text { The Edinburgh } \\
\text { Postnatal } \\
\text { Depression } \\
\text { Scale (EPDS) }\end{array}$ & $\begin{array}{l}\text { Antenatal depression was associated with a } \\
\text { greater risk of CS and postnatal depression, } \\
\text { according to a logistic multivariate } \\
\text { regression study }\end{array}$ & $\begin{array}{l}\text { risk of CS and } \\
\text { postnatal } \\
\text { depression is } \\
\text { linked to } \\
\text { antenatal } \\
\text { depression }\end{array}$ \\
\hline $\begin{array}{l}\text { Eastwood } \\
\text { et al. } \\
(2017)[18]\end{array}$ & $\begin{array}{l}\text { Retrospective } \\
\text { cohort study }\end{array}$ & $\begin{array}{l}\text { To look at the } \\
\text { association } \\
\text { between maternal } \\
\text { depressive } \\
\text { symptoms and key } \\
\text { perinatal outcomes } \\
\text { including birth } \\
\text { weight, gestational } \\
\text { age at birth, } \\
\text { breastfeeding } \\
\text { indicators, and } \\
\text { postnatal } \\
\text { depressive } \\
\text { symptoms during } \\
\text { pregnancy }\end{array}$ & $\begin{array}{l}\text { Women were identified } \\
\text { from routinely recorded } \\
\text { antenatal data and } \\
\text { determined the risk of } \\
\text { adverse perinatal } \\
\text { outcomes associated with } \\
\text { maternal depression during } \\
\text { pregnancy. Logistic } \\
\text { regression models that } \\
\text { adjusted for confounders } \\
\text { were used to determine the } \\
\text { result }\end{array}$ & $\begin{array}{l}n= \\
17,564\end{array}$ & $\begin{array}{l}\text { Edinburgh } \\
\text { Postnatal } \\
\text { Depression } \\
\text { Scale (EPDS) }\end{array}$ & $\begin{array}{l}\text { The cohort had a } 7.0 \% \text { prevalence of } \\
\text { maternal depressive symptoms during } \\
\text { pregnancy, which was strongly associated } \\
\text { with postnatal depressive symptoms. } \\
\text { Depressive symptoms before conception } \\
\text { were associated with a higher odds of low } \\
\text { birth weight and preterm birth compared to } \\
\text { women who reported lower EPDS scores in } \\
\text { the antenatal period. In the early postnatal } \\
\text { period, antenatal depression symptoms were } \\
\text { not strongly linked to non-exclusive } \\
\text { breastfeeding }\end{array}$ & $\begin{array}{l}\text { Prenatal } \\
\text { maternal } \\
\text { depressive } \\
\text { symptoms are } \\
\text { closely linked to } \\
\text { postnatal } \\
\text { depressive } \\
\text { symptoms and } \\
\text { negative } \\
\text { perinatal } \\
\text { outcomes }\end{array}$ \\
\hline $\begin{array}{l}\text { Sabri et al. } \\
\text { (2015) [19] }\end{array}$ & $\begin{array}{l}\text { Prospective } \\
\text { cohort study }\end{array}$ & $\begin{array}{l}\text { To assess the risk } \\
\text { of preterm delivery } \\
\text { and IUGR related } \\
\text { to antenatal anxiety } \\
\text { and depression } \\
\text { throughout early } \\
\text { pregnancy, as well } \\
\text { as to assess their } \\
\text { impact on fetal } \\
\text { growth and birth } \\
\text { outcome }\end{array}$ & $\begin{array}{l}\text { In the late second } \\
\text { trimester, the mother's } \\
\text { sociodemographic data, } \\
\text { EPDS, and the Beck } \\
\text { Anxiety Inventory (BAI) } \\
\text { were examined; fetal } \\
\text { growth and activity were } \\
\text { assessed during the } \\
\text { ultrasound examination, as } \\
\text { well as the doppler } \\
\text { waveforms investigation of } \\
\text { the umbilical vessels after } \\
30 \text { weeks of pregnancy }\end{array}$ & $\mathrm{n}=54$ & $\begin{array}{l}\text { Edinburgh } \\
\text { Postnatal } \\
\text { Depressive } \\
\text { Scale (EPDS) } \\
\text { and the Beck } \\
\text { Anxiety } \\
\text { Inventory (BAI) }\end{array}$ & $\begin{array}{l}\text { Women experiencing depressive and anxiety } \\
\text { symptoms in the third trimester of pregnancy } \\
\text { are more likely to have oligohydramnios, } \\
\text { IUGR, decreased placental perfusion, and } \\
\text { preterm labor, according to this study }\end{array}$ & $\begin{array}{l}\text { Various fetal } \\
\text { developmental } \\
\text { abnormalities } \\
\text { have been } \\
\text { related to } \\
\text { maternal } \\
\text { depression and } \\
\text { anxiety } \\
\text { symptoms } \\
\text { during } \\
\text { pregnancy }\end{array}$ \\
\hline $\begin{array}{l}\text { Uguz et al. } \\
\text { (2019) [20] }\end{array}$ & $\begin{array}{l}\text { Cross- } \\
\text { sectional } \\
\text { study design }\end{array}$ & $\begin{array}{l}\text { To see how } \\
\text { maternal major } \\
\text { depression, anxiety } \\
\text { disorders, and their } \\
\text { comorbidities } \\
\text { affect infants' } \\
\text { gestational age } \\
\text { and birth weight }\end{array}$ & $\begin{array}{l}\text { The study comprised } 1119 \\
\text { women, including } 26 \\
\text { women having only major } \\
\text { depression, } 125 \text { women } \\
\text { having an only anxiety } \\
\text { disorder, } 36 \text { women having } \\
\text { severe depression plus } \\
\text { anxiety disorder, and } 932 \\
\text { women having no mental } \\
\text { problems }\end{array}$ & $\begin{array}{l}n= \\
1,119\end{array}$ & $\begin{array}{l}\text { Structured } \\
\text { psychiatric } \\
\text { interviews were } \\
\text { conducted } \\
\text { using the } \\
\text { Structured } \\
\text { Clinical } \\
\text { Interview for } \\
\text { the Diagnostic } \\
\text { and Statistical } \\
\text { Manual of } \\
\text { Mental } \\
\text { Disorders, } \\
\text { Fourth Edition } \\
\text { (DSM-IV) (SCID- } \\
\text { I) }\end{array}$ & $\begin{array}{l}\text { The comorbid group had the highest } \\
\text { percentage of babies who were born } \\
\text { prematurely or with low birth weight }\end{array}$ & $\begin{array}{l}\text { During } \\
\text { pregnancy, } \\
\text { comorbidity } \\
\text { between } \\
\text { serious } \\
\text { depression and } \\
\text { anxiety } \\
\text { disorders may } \\
\text { have significant } \\
\text { unfavorable } \\
\text { consequences } \\
\text { on birth weight } \\
\text { and gestational } \\
\text { age }\end{array}$ \\
\hline $\begin{array}{l}\text { Khanghah } \\
\text { et al., } \\
2020 \text { [21] }\end{array}$ & Cohort study & $\begin{array}{l}\text { The goal of this } \\
\text { study was to see if } \\
\text { there was an } \\
\text { association } \\
\text { between antenatal } \\
\text { depression, } \\
\text { pregnancy, and } \\
\text { neonatal outcomes }\end{array}$ & $\begin{array}{l}\text { This study used a } \\
\text { convenient sample } \\
\text { approach and collected } \\
\text { data using questionnaires } \\
\text { on demographic and } \\
\text { obstetric variables, the } \\
\text { CES-D depression scale, } \\
\text { and a pregnancy outcome } \\
\text { checklist }\end{array}$ & $\mathrm{n}=394$ & $\begin{array}{l}\text { Center for } \\
\text { Epidemiological } \\
\text { Studies- } \\
\text { Depression } \\
\text { (CES-D) }\end{array}$ & $\begin{array}{l}\text { Preeclampsia, premature membrane rupture, } \\
\text { preterm delivery, cesarean section, } \\
\text { intrauterine fetal death, and intrauterine fetal } \\
\text { growth restriction were higher among } \\
\text { mothers with depression during their } \\
\text { pregnancies. The mean birth weights of } \\
\text { depressed mothers' infants were lower than } \\
\text { the infants of mothers who did not have } \\
\text { depression }\end{array}$ & $\begin{array}{l}\text { Depression is } \\
\text { associated with } \\
\text { a worse } \\
\text { pregnancy and } \\
\text { neonatal } \\
\text { outcome when } \\
\text { it occurs during } \\
\text { pregnancy }\end{array}$ \\
\hline & & & $\begin{array}{l}\text { Linear regression and } \\
\text { logistic regression were }\end{array}$ & & & & \\
\hline
\end{tabular}




\section{Cureus}

\begin{tabular}{|c|c|c|c|c|c|c|c|}
\hline $\begin{array}{l}\text { Dowse et } \\
\text { al. (2020) } \\
{[22]}\end{array}$ & $\begin{array}{l}\text { Retrospective } \\
\text { cohort study }\end{array}$ & $\begin{array}{l}\text { To see if there is } \\
\text { any connection } \\
\text { between self- } \\
\text { reported } \\
\text { depression, self- } \\
\text { reported anxiety, } \\
\text { and neonatal birth } \\
\text { outcomes using } \\
\text { EPDS scores }\end{array}$ & $\begin{array}{l}\text { used to examine the effect } \\
\text { on birth weight, gestational } \\
\text { age, admission to the NICU } \\
\text { or the SCN, birth outcome } \\
\text { (stillborn vs. live birth), and } \\
\text { Apgar scores. The } \\
\text { influence on the newborn } \\
\text { length of stay was } \\
\text { estimated using Cox } \\
\text { proportional hazards } \\
\text { regression }\end{array}$ & $\begin{array}{l}n= \\
53,646\end{array}$ & $\begin{array}{l}\text { The Edinburgh } \\
\text { Postnatal } \\
\text { Depression } \\
\text { Scale }\end{array}$ & $\begin{array}{l}\text { Women with self-reported anxiety were more } \\
\text { likely to have birth complications, have more } \\
\text { hospital admission, have worse Apgar } \\
\text { ratings, and spend longer in the hospital. } \\
\text { Babies born to women who self-identify as } \\
\text { depressed are more likely to have a lower } \\
\text { birth weight, shorter gestational age, and a } \\
\text { worse Apgar score with a longer stay in the } \\
\text { hospital }\end{array}$ & $\begin{array}{l}\text { Lower birth } \\
\text { weight, shorter } \\
\text { gestational age, } \\
\text { and lower } \\
\text { Apgar score are } \\
\text { all associated } \\
\text { with maternal } \\
\text { depression }\end{array}$ \\
\hline $\begin{array}{l}\text { Hermon et } \\
\text { al. (2019) } \\
\text { [23] }\end{array}$ & Cohort study & $\begin{array}{l}\text { To estimate the } \\
\text { risk of maternal } \\
\text { depression among } \\
\text { women } \\
\text { hospitalized in a } \\
\text { high-risk } \\
\text { pregnancy } \\
\text { department, and to } \\
\text { evaluate its } \\
\text { potential } \\
\text { association with } \\
\text { adverse perinatal } \\
\text { outcome }\end{array}$ & $\begin{array}{l}\text { During the study period, } \\
279 \text { women met the } \\
\text { inclusion criteria. Among } \\
\text { them, } 28.3 \%(n=79) \\
\text { screened positive for } \\
\text { depression ( } \geq 10 \text { points on } \\
\text { the EPDS) }\end{array}$ & $\mathrm{n}=279$ & $\begin{array}{l}\text { The Edinburgh } \\
\text { Postnatal } \\
\text { Depression } \\
\text { Scale (EPDS) }\end{array}$ & $\begin{array}{l}\text { Preterm birth, low birth weight, low Apgar } \\
\text { scores, and neonatal intensive care unit } \\
\text { (NICU) admissions were all shown to be } \\
\text { significantly higher in the screen-positive } \\
\text { group in the univariate analysis. Maternal } \\
\text { antenatal depression during hospitalization } \\
\text { was found to be an independent risk factor } \\
\text { for preterm delivery in a multivariate } \\
\text { regression model that controlled for maternal } \\
\text { age, ethnicity, gestational diabetes mellitus, } \\
\text { preeclampsia, previous preterm delivery, and } \\
\text { gestational age at admission }\end{array}$ & $\begin{array}{l}\text { Maternal } \\
\text { depression is } \\
\text { associated with } \\
\text { adverse } \\
\text { perinatal } \\
\text { outcomes }\end{array}$ \\
\hline
\end{tabular}

\section{TABLE 1: Association of depression during pregnancy and pregnancy outcomes}

SGA = small for gestational age; $A S D=$ autism spectrum disorder; PTB = preterm birth; LGA = large for gestational age; $C S=$ cesarean section; IUGR = intrauterine growth retardation; SCN = special care nursery; NICU = neonatal intensive care unit; PHQ9 = Patient Health Questionnaire9; DSM-IV = Diagnostic and Statistical Manual of Mental Disorders, Edition 4; DADP = depression and anxiety during pregnancy; CES-D = Center for Epidemiological Studies-Depression; EDPS = Edinburgh Postnatal Depression Scale.

\section{Discussion}

Women's depression is a prevalent ailment, with rates rising around childbearing years. Any numbers between $10 \%$ and $23 \%$ of women, who are 18 or older, have experienced symptoms of depression, which often include sleeplessness, hopelessness, and low energy [24,25]. Moreover, when women are evaluated, $6.5 \%$ to $13 \%$ of women screen positive for prenatal depression and these rates are similar among pregnant women and comparable non-pregnant women $[5,26]$.

There are concerns about the effects of antidepressant use during pregnancy on offspring. Antidepressant drugs' effects on growing fetuses are not well understood [15]. Antidepressants such as selective serotonin reuptake inhibitors (SSRIs) are widely administered during pregnancy. These medications have been shown to pass the placenta, and serotonin is essential for embryonic brain development [27]. Antidepressants are sometimes avoided by women who are pregnant or planning to get pregnant.

Between $1 \%$ and $13 \%$ of pregnant women receive treatment for depression during their pregnancy, as indicated by antidepressant prescriptions [11]. According to studies, women with a history of depression who stopped using antidepressants during pregnancy are more likely to relapse than those who keep taking them [5]. Discontinuation of any depression care is quite common during pregnancy. The rate of antidepressant prescription is approximate $70 \%$ during pre-pregnancy of depressed women. This rate drops to $27 \%$ during pregnancy [28]. Pregnancy is a significant driver of antidepressant drug discontinuation, and most women do not get additional antidepressant prescriptions after six weeks of pregnancy [5]. Despite depression's seriousness, screening for depression is underutilized, which precludes treatment and efforts to prevent the escalation of symptoms and associated consequences. Even when depression is diagnosed, it often remains untreated [5]. Although women would normally be given screening and treatment before conception, many women go into pregnancy with untreated depression [5].

Depression Measures

Depression during pregnancy was the primary exposure variable in this study. Most of the studies screened and reviewed in this study were assessed using the Edinburgh Postnatal Depression Scale (EPDS) (studies in references $[1,3,4,9,10,16-19,22,23])$. However, the threshold for EPDS differs from study to study. It indicates that all these studies considered a minimum score of EPDS to determine gestational depression. Few others utilized other measures, i.e., the Center for Epidemiological Studies-Depression (CES-D) scale, the 9-item 
Patient Health Questionnaire (PHQ-9), and other custom questionnaires (studies in references $[5,8,11$ $15,20,21])$.

Factors Associated With Depression During Pregnancy

Various factors related to mental during pregnancy have been reported in these studies. According to Choi et al. (2014), the depressed group had more pregnant women with low levels of education than the nondepressed group. In addition, the depressed group had more unemployed women than the nondepressed group. The marital status of the two groups differed significantly, with the depressed group having more women who were single or had remarried than the nondepressed group. Women in extended families were more prevalent in the non-depressed group than in the depressed group [10].

Benatar et al. (2020) showed that black participants are considerably more likely to be depressed than white participants, while Hispanic participants are significantly less likely to be depressed. Women with a previous pregnancy are significantly more likely to be depressed than those without, as are women whose pregnancy is unintended compared with those who intended their pregnancy. Women who are married or in a relationship are much less likely to be depressed than those who are not married nor in a relationship. Having experienced intimate partner violence (IPV) is substantially associated with depression. Women who report challenges to attend antenatal appointments are substantially more likely to be depressed than women who report no barriers [5]. In addition, Li et al. (2020) reported that women under the age of 25 were more likely to suffer from antenatal depression than their counterparts [16].

\section{Maternal Complications}

According to Weobong et al. (2014), mothers with antenatal depression used to have a considerably higher risk of severe peripartum complications, postpartum problems, cesarean section and/or instrumental delivery, and prolonged labor. Heavy bleeding, a tear in the vaginal wall, placental abnormalities, and convulsions were four of the eight peripartum complications that depressive women were more likely to report antenatally. Further analysis showed that postpartum complications, such as fever and other major complications including leaking urine/feces, were substantially more common among antenatally depressed women. Additionally, it was revealed that women suffering from prenatal depression were much less likely to use a bed net during their pregnancy. According to their findings, there was no link between prenatal depression and antenatal care attendance, birth in a health facility, immediate breastfeeding initiation, or exclusive breastfeeding during the neonatal period [8].

According to Al Rawahi et al. (2020), there is a strong link between antenatal depression and CS delivery, which is supported by previous research. It was found that the women suffering from prenatal depression have higher levels of anxiety and fear of labor, resulting in lower pain tolerance, a higher need for epidural analgesia, and a higher rate of CS. Furthermore, psychological distress has been shown to impede uterine contractility, resulting in protracted labor, inability to progress, and eventually fetal distress, all of which could raise the chance of CS. [17]. Another study conducted by Khanghah et al. showed that preeclampsia, preterm rupture of the membranes, premature delivery, cesarean section, intrauterine fetal death, and intrauterine fetal growth limitation were all considerably greater among mothers with severe depression compared to those who did not have depression [21].

\section{Perinatal Complications}

In a study conducted in the United Kingdom, Eastwood et al. (2017) found that guilt was a major concern for depressive mothers who had breastfeeding difficulties, regardless of whether they continued nursing. This problem was linked to thoughts and sentiments of not being a perfect mother. It also showed that even after controlling for socioeconomic level, prenatal and postnatal depression are still significant contributors to poor baby feeding behaviors. Mother's mental and physical concerns, psychosocial factors (such as a lack of financial resources or inadequate family support), and reduced health-seeking behaviors are all plausible pathways for maternal depression's effect on infant feeding practices [18].

\section{Fetal Outcomes}

Benatar et al. (2020) show that women who screen positive for depression have a 2.5 percentage point higher rate of preterm birth, a 2.4 percentage point higher probability of their infant being low birth weight, and a 2.6 percentage point higher probability of $\mathrm{C}$-section birth than women who are not depressed. Women who screen positive for depression are also 3.7 percentage points less likely to report initiating breastfeeding in the postpartum than other women [5].

According to Fekadu Dadi et al., although there is no direct link between prenatal depression and preterm birth, their study revealed that preterm birth was 4.38 and 4.99 times more common in individuals with poor spouse support and poor stress coping ability than in those with good spouse support and good stress coping ability, respectively. In the path analysis, depression had a significant indirect effect on preterm birth via partner support and delivery fear, both of which had independent direct effects on preterm birth [9]. 
Despite the uneven link between maternal depression and delivery outcomes, a biologically feasible explanation exists, and according to Smith et al. (2015) and Fekadu Dadi et al. (2020), researchers have found that depression stimulates the hypothalamus-pituitary-adrenal (HPA) system during pregnancy, resulting in increased cortisol hormone output. The placental clock is a scenario in which depression during pregnancy stimulates the synthesis of corticotrophin-releasing hormone (CRH) from the placenta, causing preterm labor. Chronic stress can also impair the body's ability to regulate the synthesis of inflammatory proteins. As a result, inflammation and cortisol are not properly regulated, which can lead to premature contractions and birth. Because depression is a stressor, it probably plays a role in preterm birth. Experts also feel that SGA is linked to depression because it disrupts the neuroendocrine balance. The hormonal end products of hypo or hyperactivity of the hypothalamic-pituitary-adrenal (HPA) axis (i.e., cortisol and norepinephrine) may affect uterine artery blood flow, parturition, and fetal development and growth $[9,15]$. Effects of depression during pregnancy on fetal outcomes are depicted below in Figure 2.

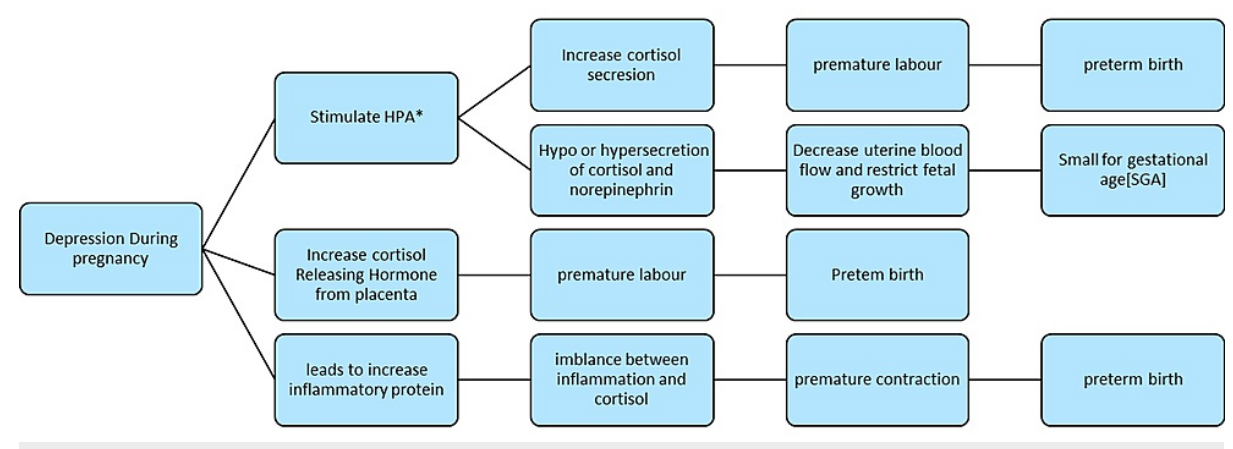

FIGURE 2: Effect of depression during pregnancy on fetal outcomes

*HPA: hypothalamus-pituitary-adrenal.

Furthermore, Fekadu Dadi et al. observed that the adjusted risk of stillbirth was 3.22 times greater among study participants who were depressed during their pregnancy. The path analysis found that prenatal depression had a slight direct effect on stillbirth. However, stillbirth risk was reduced by $73 \%$ in research participants who had good stress coping skills [9].

According to Yang et al. (2017), LBW (birth weight less than $2500 \mathrm{gm}$ ) is the leading cause of prenatal mortality and morbidity, as well as an increased risk of noncommunicable diseases including diabetes and cardiovascular disease later in life. Low birth weight accounts for more than $15 \%$ of all births worldwide, with a higher prevalence in low-income nations. Women with depression and anxiety during pregnancy (DADP), who experienced a preterm birth, had a higher risk of having an LBW baby, according to this study, whereas women with DADP who had a full-term birth did not. In this study, prenatal depression was shown to be prevalent in $18.6 \%$ of pregnant women, antenatal anxiety was found to be prevalent in $13.0 \%$ of pregnant women, and $9.3 \%$ of pregnant women experienced both antenatal depression and anxiety [13]. Therefore, anxiety and depression could be important associations to look for in a pregnant woman.

Hagberg et al. (2018) suggested that women who experience depression during pregnancy have a higher risk of having a child with autism spectrum disorder (ASD) than women who are not affected regardless of antidepressant use. The risk was marginally higher in women with treated depression compared to those with untreated depression; however, the fact that the risk of ASD was not increased in women who were taking antidepressants for other reasons suggests that antidepressants are not responsible. Rather, the findings show that the modest increase in risk associated with antidepressant usage is due to differences in depression intensity. Finally, independent of the existence of anxiety/other psychiatric disorders, the risk of ASD was enhanced among children of mothers with treated or untreated depression; however, the risks were higher among depressed women with comorbid anxiety/psychological disorder [11].

\section{Postpartum Follow-up}

According to Al Rawahi et al. (2020), women with prenatal depression have a higher chance of acquiring postnatal depression than women who do not have antenatal depression [17]. A study from the United States indicated that women who had poor mental health during the prenatal period were 11 times more likely to acquire poor mental health during the postnatal period [29]. In another study, 23\% of women with postnatal depression said their depressive symptoms began during pregnancy [30]. It was also discovered that women who had previously suffered postnatal depression have a higher probability of experiencing postnatal depression after consecutive deliveries [31].

Ultimately, it was indicated that maternal depression during pregnancy may negatively influence motherinfant health outcomes. To prevent this adverse outcome, depression should be screened, monitored, and 


\section{Limitation}

Our paper shows some limitations: papers in another language were not included and studies published before 2014 were disregarded, thus many valuable studies could have been missed; also, most of the studies, although focused on analyzing both presence and severity of depressive symptoms, do not provide a structured diagnosis of depression in line with the criteria established in the Diagnostic and Statistical Manual of Mental Disorders or the International Classification of Diseases. Some studies did not deploy the same structured approach for gestational length, spontaneous abortion, and birth weight, which are the variables that could be associated with depression during pregnancy, antidepressants, or both. Comparative research on other outcomes, i.e., neonatal adaptation syndrome, longer-term behavior effects, etc., is key areas for further research. Finally, the lack of a control group (i.e., depressed medicated mothers) in some studies greatly reduces the significance of such results.

\section{Conclusions}

We observed higher risks of preterm birth, small for gestational age, stillbirth, low birth weight, and ASD when we took a systematic approach to evaluate the impact of untreated depression on pregnancy, and maternal morbidity can lead to perinatal complication, increased operative delivery, and postpartum depression. Our findings have substantial therapeutic implications for pregnant women and health care professionals because they imply the need for increased surveillance for adverse outcomes in women with untreated depression during pregnancy. Antenatal depression must be detected and treated as soon as possible. Physicians should perform a risk-benefit analysis and carefully detail the risks of untreated depression for both the mother and the fetus once the diagnosis has been verified. Nonpharmacologic therapy for mild-to-moderate depression could be administered first, coupled with a referral to a psychologist if one is available. Psychotherapy alone may not be enough for more critically ill patients, and further antidepressant treatment may be required. To avoid recurrence after treatment has begun, it is vital to evaluate and ensure proper follow-up into the postpartum period.

\section{Additional Information \\ Disclosures}

Conflicts of interest: In compliance with the ICMJE uniform disclosure form, all authors declare the following: Payment/services info: All authors have declared that no financial support was received from any organization for the submitted work. Financial relationships: All authors have declared that they have no financial relationships at present or within the previous three years with any organizations that might have an interest in the submitted work. Other relationships: All authors have declared that there are no other relationships or activities that could appear to have influenced the submitted work.

\section{References}

1. Xu L, Li J, Pu Y, Zhou C, Feng S, Luo Q: Effect of prenatal depression during late pregnancy on maternal and neonatal outcomes. Clin Exp Obstet Gynecol. 2020, 47:681-6. 10.31083/j.ceog.2020.05.5398

2. Depression during pregnancy and preterm birth; a prospective cohort study carried out among women attending antenatal clinic at Pumwani Maternity Hospital. (2016). Accessed: May 1, 2021: http://erepository.uonbi.ac.ke/handle/11295/100375.

3. Mochache K, Mathai M, Gachuno O, Vander Stoep A, Kumar M: Depression during pregnancy and preterm delivery: a prospective cohort study among women attending antenatal clinic at Pumwani Maternity Hospital. Ann Gen Psychiatry. 2018, 17:31. 10.1186/s12991-018-0202-6

4. Szegda K, Bertone-Johnson ER, Pekow P, Powers S, Markenson G, Dole N, Chasan-Taber L: Depression during pregnancy and adverse birth outcomes among predominantly Puerto Rican women. Matern Child Health J. 2017, 21:942-52. 10.1007/s10995-016-2195-6

5. Benatar S, Cross-Barnet C, Johnston E, Hill I: Prenatal depression: assessment and outcomes among Medicaid participants. J Behav Health Serv Res. 2020, 47:409-23. 10.1007/s11414-020-09689-2

6. Marcus SM, Flynn HA, Blow FC, Barry KL: Depressive symptoms among pregnant women screened in obstetrics settings. J Womens Health (Larchmt). 2003, 12:373-80. 10.1089/154099903765448880

7. PRISMA flow diagram. (2021). Accessed: May 1, 2021: https://estech.shinyapps.io/prisma_flowdiagram.

8. Weobong B, ten Asbroek AH, Soremekun S, Manu AA, Owusu-Agyei S, Prince M, Kirkwood BR: Association of antenatal depression with adverse consequences for the mother and newborn in rural Ghana: findings from the DON population-based cohort study. PLoS One. 2014, 9:e116333. 10.1371/journal.pone.0116333

9. Fekadu Dadi A, Miller ER, Woodman RJ, Azale T, Mwanri L: Effect of antenatal depression on adverse birth outcomes in Gondar town, Ethiopia: a community-based cohort study. PLoS One. 2020, 15:e0234728. 10.1371/journal.pone.0234728

10. Choi SK, Park YG, Park IY, Ko HS, Shin JC: Impact of antenatal depression on perinatal outcomes and postpartum depression in Korean women. J Res Med Sci. 2014, 19:807-12.

11. Hagberg KW, Robijn AL, Jick S: Maternal depression and antidepressant use during pregnancy and the risk of autism spectrum disorder in offspring. Clin Epidemiol. 2018, 10:1599-612. 10.2147/CLEP.S180618

12. Flynn HA, McBride N, Cely A, Wang Y, DeCesare J: Relationship of prenatal depression and comorbidities to infant outcomes. CNS Spectr. 2015, 20:20-8. 10.1017/S1092852914000716

13. Yang S, Yang R, Liang S, et al.: Symptoms of anxiety and depression during pregnancy and their association 
with low birth weight in Chinese women: a nested case control study. Arch Womens Ment Health. 2017, 20:283-90. 10.1007/s00737-016-0697-2

14. Nutor JJ, Slaughter-Acey JC, Giurgescu C, Misra DP: Symptoms of depression and preterm birth among black women. MCN Am J Matern Child Nurs. 2018, 43:252-8. 10.1097/NMC.0000000000000464

15. Smith KF, Huber LR, Issel LM, Warren-Findlow J: The association between maternal depression during pregnancy and adverse birth outcomes: a retrospective cohort study of PRAMS participants. J Community Health. 2015, 40:984-92. 10.1007/s10900-015-0022-4

16. Li X, Gao R, Dai X, et al.: The association between symptoms of depression during pregnancy and low birth weight: a prospective study. BMC Pregnancy Childbirth. 2020, 20:147. 10.1186/s12884-020-2842-1

17. Al Rawahi A, Al Kiyumi MH, Al Kimyani R, et al.: The effect of antepartum depression on the outcomes of pregnancy and development of postpartum depression: a prospective cohort study of Omani women. Sultan Qaboos Univ Med J. 2020, 20:e179-86. 10.18295/squmj.2020.20.02.008

18. Eastwood J, Ogbo FA, Hendry A, Noble J, Page A: The impact of antenatal depression on perinatal outcomes in Australian women. PLoS One. 2017, 12:e0169907. 10.1371/journal.pone.0169907

19. Sabri Y, Nabel H: The impact of anxiety and depression during pregnancy on fetal growth and the birth outcome. Egypt J Psychiatry. 2015, 36:95-100.

20. Uguz F, Yakut E, Aydogan S, Bayman MG, Gezginc K: The impact of maternal major depression, anxiety disorders and their comorbidities on gestational age, birth weight, preterm birth and low birth weight in newborns. J Affect Disord. 2019, 259:382-5. 10.1016/j.jad.2019.08.076

21. Khanghah AG, Khalesi ZB, Hassanzadeh RA: The importance of depression during pregnancy. JBRA Assist Reprod. 2020, 24:405-10. 10.5935/1518-0557.20200010

22. Dowse E, Chan S, Ebert L, et al.: Impact of perinatal depression and anxiety on birth outcomes: a retrospective data analysis. Matern Child Health J. 2020, 24:718-26. 10.1007/s10995-020-02906-6

23. Hermon N, Wainstock T, Sheiner E, Golan A, Walfisch A: Impact of maternal depression on perinatal outcomes in hospitalized women-a prospective study. Arch Womens Ment Health. 2019, 22:85-91. 10.1007/s00737-018-0883-5

24. Ahluwalia IB, Holtzman D, Mack KA, Mokdad A: Health-related quality of life among women of reproductive age: Behavioral Risk Factor Surveillance System (BRFSS), 1998-2001. J Womens Health (Larchmt). 2003, 12:5-9. 10.1089/154099903321154086

25. Chronic illness and mental health: recognizing and treating depression. (2018). Accessed: July 31, 2018: https://www.nimh.nih.gov/health/publications/chronic-illness-mental-health/index.shtml.

26. Chaudron LH: Complex challenges in treating depression during pregnancy. Am J Psychiatry. 2013, 170:1220. 10.1176/appi.ajp.2012.12040440

27. Lattimore KA, Donn SM, Kaciroti N, Kemper AR, Neal CR Jr, Vazquez DM: Selective serotonin reuptake inhibitor (SSRI) use during pregnancy and effects on the fetus and newborn: a meta-analysis. J Perinatol. 2005, 25:595-604. 10.1038/sj.jp.7211352

28. Bennett IM, Marcus SC, Palmer SC, Coyne JC: Pregnancy-related discontinuation of antidepressants and depression care visits among Medicaid recipients. Psychiatr Serv. 2010, 61:386-91. 10.1176/ps.2010.61.4.386

29. Witt WP, Wisk LE, Cheng ER, et al.: Poor prepregnancy and antepartum mental health predicts postpartum mental health problems among US women: a nationally representative population-based study. Womens Health Issues. 2011, 21:304-13. 10.1016/j.whi.2011.01.002

30. Watson JP, Elliott SA, Rugg AJ, Brough DI: Psychiatric disorder in pregnancy and the first postnatal year. $\mathrm{Br}$ J Psychiatry. 1984, 144:453-62. 10.1192/bjp.144.5.453

31. Robertson E, Grace S, Wallington T, Stewart DE: Antenatal risk factors for postpartum depression: a synthesis of recent literature. Gen Hosp Psychiatry. 2004, 26:289-95. 10.1016/j.genhosppsych.2004.02.006 